\title{
The Terrorist Threat to the World Political System
}

\author{
Marina M. Lebedeva *
}

\section{Introduction}

Terrorism as a method of political struggle has been practiced since ancient times, and in this sense it is no different today. Yet, at the turn of the twenty-first century, terrorism has assumed particularly threatening forms, sparking almost universal concern. What are the reasons behind this shift? This question is met with various ready answers. Some point to the increased scope of modern acts of terror and the internationalization of terrorism; others cite dissatisfaction among the countries of the so-called "global South" with the continuing (and in some respects broadening) rift between the "North" and "South," which results in ever greater involvement of such countries in acts of terror. Yet other observers point out that terrorists have embraced sophisticated scientific and technological approaches, thus increasing the deadly consequences of their acts. For the most part, these factors contribute to the threat of terrorism. Yet the main reason that terrorism is especially dangerous today is the fact that, during a period of crisis within the world political system, an alternative project, or ideology, is being promoted. A number of organizations are attempting to bring this system to life by terrorist means.

\section{The Westphalian Political System: Its Evolution and Crisis}

The world's political system, known as the Westphalian or state-centered system, began to take shape in Europe over 350 years ago in the wake of the Thirty Years' War, which for various reasons (religious, dynastical, territorial, etc.) engulfed a large part of Europe. The signing of the Peace of Westphalia in 1648 became a milestone event in historical development, heralding the formation of a political system that eventually spread on a global scale. At the core of this system was the idea of state sovereignty, which was a major social innovation of the time, making it possible to overcome the countless confessional, territorial, ethnic, and other conflicts that tore Europe apart in the mid-seventeenth century.

We should understand that those who searched for solutions to these conflicts proceeded based on the interests of the conflicting sides, and not on the basis of their values. The French researcher Jean-Marie Guehenno writes that the creators of the Peace of Westphalia understood only too well that the world order they had shaped could not be built on values, and in particular religious values, which are nonnegotiable and not

Dr. Marina M. Lebedeva is a Professor and the Chair of World Politics at the Moscow State Institute of International Relations (MGIMO-University). 
subject to concession. For this very reason the nation-state model of the world was founded on national interests, an area in which compromise solutions can be found. ${ }^{1}$

We may joke, paraphrasing the witticism of George Orwell, that all countries are no doubt equal, but some are more equal than others. Nonetheless, in legal terms the doctrine of national sovereignty equalized all countries, regardless of their different characteristics (form of government, territory, military and economic power, etc.), making it possible to lay the foundations of international law. To use a mathematical metaphor, national sovereignty became a "common denominator" of sorts for numerous and diverse actors, making it possible to regulate their activity inside and outside the borders of nation-states, whereas the state itself became a kind of basic structural unit of the political system.

Clearly, the emergence of the doctrine of state sovereignty did not prevent countless violations of sovereignty that led to numerous wars, including two World Wars. However, these were violations of international law-i.e., violations of the rules of international interaction. Further, it is noteworthy that, while wars were unleashed by one country with the intent of occupying the territory of other countries, the nation-state system as such was not challenged. In fact, despite the occurrence of two devastating World Wars in the twentieth century, carried out by traditional state actors, the political system of the world remained unchallenged.

The Westphalia model was not static during the centuries that followed its appearance. It developed, transformed, and expanded, spreading to an ever-increasing number of countries. It was a Western project in the sense that its conception originated in Western Europe. From there it spread to other continents, through both the diffusion of ideas and colonial conquests.

The logical climax of the Westphalian system occurred toward the end of the twentieth century. The colonial system collapsed, and the world found itself made up almost entirely of independent states. In the late twentieth and early twenty-first centuries, the United States came to symbolize this outcome as the world's undisputed leader in the political and economic arena and in the sphere of mass culture. ${ }^{2}$

While these epochal shifts were taking place, other actors developed and began to actively function within the nation-state model: intergovernmental organizations, international nongovernmental organizations (NGOs) and movements, transnational corporations, intrastate regions and megalopolises, and other transnational actors. While such entities had existed earlier, the scope of their activities in the international arena is fundamentally new, and on a number of issues they have started to interact on a level commensurate with governments. The breakthroughs in communication and information technologies in the late twentieth century further intensified various actors' transnational activities. As a result, the borders of nation-states have become to a significant degree transparent, which has hastened the processes of globalization.

1 Jean-Marie Guehenno, “Globalization and the International System,” Journal of Democracy 10:1 (January 1999): 22-35.

2 Joseph Nye, The Paradox of American Power: Why the World's Only Superpower Can't Go It Alone (New York: Oxford University Press, 2002). 
Moreover, with the turn of the new millennium, the state itself has experienced major changes. While integration processes have intensified in some regions (the best example being the European Union), other regions have experienced disintegration, while still others have seen the emergence of failed states unable to control their own territories. Finally, we have witnessed the emergence of states that attempt to threaten their neighbors in one way or another, bringing down on themselves consequences that are not easily predictable in the environment of globalization. All of these results have eroded the state-centered political system of the world.

It is worth noting the general background of the late twentieth and early twenty-first centuries, when the world political system came face to face with these challenges. Perhaps above all others, a major continuing problem has been the rift between the North and South. Several developments-including the fact that some states (primarily new industrial states) are now successfully competing in the socioeconomic sphere, and that zones of the "South" have developed in the North and zones of the "North" have developed in the South-are not helping the problem. Instead, the emergence of more successful states has tended to evoke a response of hatred. In the late autumn of 2005, disturbances organized by immigrants from African and Asian countries in the suburbs of French and other European cities provided a vivid example of the kind of social resentment that can result when globalization places new neighbors uneasily together.

The crisis of the modern world political system is partially due to the scientific and technical revolution, which, as James Rosenau has argued, unleashed the process of globalization, making national borders transparent and simplifying interaction among various actors. However, the origins of the crisis have other roots as well. The products of the scientific and technical revolution have enabled a small group of people to cause tremendous damage, something that only states were able to do in the past, thereby bringing science-fiction scenarios to life.

All of this is happening against the backdrop of a paradoxical situation. On the one hand, growing interdependence has become possible, owing to the development of modern communication, information, and other technologies. On the other hand, the same technologies enable certain organizations or structures (including governments) to operate autonomously for extended periods of time. This is accomplished by various means, such as using network connections outside of the organization that can provide members with a supply of the needed resources, funding, information, and (in some cases) weapons. Another method is to create a product to substitute for an unavailable product, using scientific and technical innovations (for example, during the apartheid era, South Africa developed technologies to produce gasoline by processing coal). Under such conditions, isolating terrorist formations and preventing them from developing certain resources can be extremely difficult.

\section{Alternative Projects}

In the current geopolitical climate, organizations like $\mathrm{Al}$ Qaeda propose an alternative to political and social relations in the world (not just in the region-in this case, the 
Middle East), an alternative founded on the norms of Islam. This is most often emphasized in U.S. literature, but has recently been mentioned by Russian researchers as well. $^{3}$ A. Malashenko, for example, writes: "The Islamic alternative in its broad sense represents a collective response of Islamdom to the external challenge." ${ }^{4}$

The very fact that this alternative is not accepted by the majority of the planet's population (by all estimates, the number of Islamic followers is significantly smaller than 50 percent of the global population) is no doubt seen as a challenge to spread the message to the rest of the world by those who espouse it. Yet it does not represent a global threat unless terrorist methods are employed.

Of course, alternatives to the nation-state model, each with its own approach to political organization, had existed before. While there is nothing new about a global scheme of world order, the Islamist response does have some unique characteristics. Yet it is important to keep in mind that it is not unprecedented; parallels between ideologies, faiths, and values were drawn a long time ago.

For instance, communism in its original Marxist sense was an alternative proposal to create new political relations based on a new structural unit-the class - and consequently a new political system. Interestingly, communism also emerged during a time of a crisis, when capital largely completed its "reclamation" of the territorial space of the nation-state and started to move en masse beyond its borders. However, in the course of the practical implementation of communism in the Soviet Union and subsequently in other countries, the idea of a global transformation of sociopolitical relations was relegated to an indefinite future, and efforts focused on the level of the nationstate. Furthermore, the nation-state itself as the main structural unit of the political system of the world not only survived, but even started to strengthen.

Another important aspect is that terrorism was never used as the prime method of implementing communism. Various leftist extremist organizations (the Red Brigades in Italy, the Red Army Faction in Germany, the Tupac Amaru and the Shining Path in Peru, to name only a few) acted locally and nationally, and during the Cold War they did not act as "representatives" of the Socialist bloc. More importantly, many of them perceived the leaders of both blocs - the United States and the Soviet Union-as their enemies. While members of such organizations considered it their calling to affect world events, they paid little attention to the ideological aspect of their activity, i.e. the transformation of political relations. ${ }^{5}$

An attempt, albeit an amorphous one, to realize an alternative to the nation-state formulation was made by the Japanese religious sect Aum Shinrikyo. The sect, through terrorist means, sought to bring about the end of the world, thereby ensuring their own salvation. They did not offer any alternative principles for organizing sociopolitical ties and relations, but simply sought to destroy existing relations, which is why such

3 See, for example, Zeyno Baran, "Fighting the War of Ideas," Foreign Affairs 84:6 (November/ December 2005).

4 A. Malashenko, Islamskaya alternativa i islamistskiy proekt (Moscow: Ves mir, 2006), 66.

5 Bruce Hoffman, Inside Terrorism (New York: Columbia University Press, 1998). 
doomsday efforts can be called "attempts" at transforming political relations only with reservations.

The example of Aum Shinrikyo is significant from both political and psychological viewpoints. It points to dissatisfaction with the existing political system of the world and a readiness to destroy it by terrorist means, including the use of weapons of mass destruction (WMD); the group carried out attacks using sarin gas in the Tokyo subway in 1995. This is the first and so far only time that a terrorist organization has used WMD. It clearly shows that the problem of terrorism is compounded by the problem of relatively portable and accessible weapons of fearsome destructive power and lethality.

Another point central to understanding the phenomenon of global terrorism is that Aum Shinrikyo managed to attract a large following in different countries over a relatively short period of time. In some countries, it reached all the way to the governmental level. This illustrates how easily a terrorist organization can attract followers.

Finally, perhaps the most significant point is that Aum Shinrikyo emerged in a culture that is not related to the Arabic or Muslim world. This indicates that the problems driving dissatisfaction with the state-centered global political order stem primarily not from Arab or Muslim culture, as it would sometimes appear, but from the existing political system of the world.

Thus, truly global terrorist movements, as personified by Al Qaeda, have the following characteristics:

- They attempt to implement their alternative to the world political system through terrorist means. During a crisis in the existing world system, Al Qaeda proposes to replace the current system with "an alternative version of social-and hence government-order founded on the laws of the Sharia, social justice, with a strong ruler."6

- They take advantage of a fundamentally new stage in scientific and technical progress, which enables individuals or small groups to exert powerful influence on the world, and which also enables them to operate comparatively autonomously despite the ongoing processes of globalization.

- Global terrorist organizations can draw upon a deep pool of individuals alienated from modern sociopolitical relations and easily recruit new generations of terrorists.

- The proposed sociopolitical system is founded on Islamic values and on relations that not only correspond to Islam, but which, more significantly, are already partially realized on at least two of the four levels singled out by Malashenko: the local and the national. ${ }^{7}$ Therefore, the global system being implemented has a quite specific and already "verified" nature.

- The Islamist alternative to the global political system originated in a very complex region riddled with discord. These conflicts include the Israeli-Palestinian,

6 Malashenko, Islamskaya alternativa i islamistskiy proekt, 48.

7 Ibid. 
Iraqi, and Afghan conflicts, along with numerous disputes in the Caucasus, which is not far removed from the Middle East and is related in confessional terms, to name just a few. The Islamic alternative provides a fundamentally new ideological basis for all of these conflicts, transforming isolated struggles into "civilizational" conflicts and rapidly expanding the social base of support for this alternative.

By placing terrorism aimed at achieving an alternative to the world order in a separate category, I emphasize that we are not speaking of terrorism as a method. The method of terrorism - that is, the use of violence against non-combatants to achieve political or social ends-is absolutely unacceptable and has no political, legal, moral, or other justification, regardless of the intents and purposes for which it is used. Nonetheless, it is extremely important to understand what lies behind the method itself - the aims, values, conceptions of political world order: in short, the ideology — in order to effectively counter terrorism.

To illustrate the need to analyze the values behind terrorism, let us consider the example of the most dangerous scenario of events, the possibility of terrorists using WMD. According to most specialists, if terrorists resort to WMD, these will most probably be chemical weapons because of their greater availability from a technical standpoint and their relative ease of application. ${ }^{8}$ Incidentally, the only case of WMD being used by terrorists—-the 1995 Aum Shinrikyo attack in the Tokyo subway—fully confirms this assumption.

However, the logic behind different terrorist groups' actions may be totally different, depending on their values, ideology, and possible aims. For a terrorist organization such as Al Qaeda that proposes an alternative to the global order, it is of primary importance to demonstrate its power and ability to influence the Western world and its infrastructure. On 11 September 2001 terrorists attacked symbols of Western economic and military might - the World Trade Center and the Pentagon — but they also did so with symbolic tools - ordinary passenger aircraft used as weapons. They targeted the transport infrastructure in Madrid (rail transport) on 11 March 2004; in London (urban mass transit) on 7 July 2005; and again in London, when authorities averted another possible terrorist attack (air transport) on 9 August 2006.

In a situation where terrorists might resort to WMD, choosing nuclear weapons - in particular the so-called "dirty bomb" option—would be a psychological victory for terrorists, because it would show that they had joined the "nuclear club," which is open only to a few select countries. For the mass consciousness it is not important whether the nuclear weapon is technologically advanced or quite primitive. What matters is the very fact that nuclear weapons will have been used as a means of demonstrating power by a non-state group.

8 See, for example, V. Orlov and A. Khlopkov, “Na povestke dnya - superterrorism,” Nezavisimoye Voennoe Obozrenie (21 September 2001). 


\section{Counterterrorism: New Approaches}

How should the struggle against terrorism be shaped? Currently, the struggle is primarily targeted against the terrorist method itself. Various strategies have been employed, ranging from military and legal measures to psychological influence. While acknowledging the significance of these measures, one must admit that they are hardly sufficient.

Terrorism is a political phenomenon. Consequently, until the political problems that give rise to contemporary global terrorism are resolved, the struggle against it will not be successful. Although the different conditions that breed support for terrorism are taken into account when developing counterterrorism measures (such as eliminating significant social inequality, including the imbalance between the North and the South), the goal of building a world political system that would be more responsive to present-day realities is almost entirely excluded from the set of challenges analyzed as part of counterterrorist measures. This is partly because issues connected with the formation of the world political system cannot be resolved overnight, but it is also because terrorist activity requires an immediate response. Nonetheless, political considerations should play an essential role in the comprehensive struggle against terrorism, especially considering the political nature of the phenomenon of terrorism. It is around this understanding that nations must build their military, psychological, economic, and other strategies of fighting terrorism.

The world now faces a situation similar to the one that Europe faced in 1648. At that time, the invention of the principle of national sovereignty made it possible to defuse numerous conflicts (ethnic, religious, etc.) that were tearing the continent apart. However, the world now faces a far more complex task. First, the political system must be built on a completely different scale. This pertains both to modern geographical parameters (with the geography in question no longer being limited to the European continent, as was the case in the seventeenth century) and to the far greater number of actors. Second, modern actors differ along a much greater number of vectors: interests, aims, resources, the ability to influence the political development of the world, principles of internal organization, etc. It is very difficult to find a common denominator in this situation.

Attempts to define a new standard unit were made in the process known as Westernization. Thomas Friedman sees the attributes of a single (global) world order in the Western models of daily life, common to nearly all countries: the Internet, fax, cellular communication, etc. ${ }^{9}$ Francis Fukuyama, on the other hand, primarily sees these common denominators as residing in Western democratic values. ${ }^{10}$

9 Thomas L. Friedman, The Lexus and the Olive Tree: Understanding Globalization (New York: Farrar, Straus and Giroux, 1999); Friedman, The World Is Flat: A Brief History of the Twenty-first Century (New York: Farrar, Straus and Giroux, 2005).

10 Francis Fukuyama, “The End of the History?” The National Interest (Summer 1989): 3-18; Fukuyama, "Second Thoughts. The Last Man in a Bottle," The National Interest (Summer 1999): 16-33. 
Attempts to intensify Westernization have met with failure. Moreover, they often provoke rejection of Western civilization as a whole, or produce a distorted interpretation of the ideals of Western culture. ${ }^{11}$ This results in various expressions of resistance to Westernization.

The difficulties encountered in efforts to bring the world political system into closer harmony with modern realities often discourage actors from attempting any changes. Psychologically, it is easy to understand those who support the preservation of the status quo. After all, this system worked in the past. In the short term, a strategy to preserve the existing political system is obviously possible. However, it is clear that various forceful attempts to change the world political system will be made, including those carried out by terrorists. Thus, the task of a calculated construction of a new world political system (or modifying the existing system) that better reflects presentday realities remains on the agenda.

While pursuing this task (which has no quick solutions), it is important to actively involve various transnational actors in the fight against terrorism. Today, international collaboration against terrorism is restricted to intergovernmental cooperation within bilateral and multilateral frameworks, and to cooperation at the level of international organizations such as the United Nations. While acknowledging the significance and precedence of such cooperation in the antiterrorist struggle, it is hardly justifiable to ignore the potential of other transnational actors.

Transnational actors, which originated at the heart of the state-centered political system, generally act in accordance with the model's principles. For this reason, transnational actors are interested in a gradual, evolutionary transformation of the modern world political system, not in its extinction. Moreover, acts and threats of terrorism cause material and financial losses, and introduce an element of instability. These factors complicate the operations of transnational actors, which rely on predictability across national boundaries. It was not by chance that speakers during the July 2006 G8 Summit in St. Petersburg underscored the need to involve business in the fight against terrorism. $^{12}$

It is noteworthy that multilateral and multilevel cooperation in the international arena has become widespread around the turn of the millennium. It is most discernible in the environmental sphere. For instance, representatives of NGOs and business joined governmental representatives to attend the World Summit on Sustainable Development hosted in Johannesburg in $2002 .{ }^{13}$ Similar processes, which involve many countries and actors in the resolution of problems, have been observed lately in other spheres. For example, the 2005 Tunis Summit on the Information Society drew more

11 See, for example, A.P. Tsygankov, Whose World Order? Russia's Perception of American Ideas after the Cold War (Notre Dame, IN: University of Notre Dame Press, 2004).

12 “G8 Summit Declaration on Counter-Terrorism,” St. Petersburg (16 July 2006). Available at: http://en.g8russia.ru/docs.

13 M.M. Lebedeva, "Ekologicheskie problemy v mezhdunarodnikh otnosheniyakh," in Sovremennye mezhdunarodnie otnosheniya i mirovaya politika, A.V. Torkunova, ed. (Moscow: Prosveshchenie, 2004), 366-80. 
than 11,000 participants representing governmental structures, business communities, and civil society institutions from 175 countries, as well as a number of international organizations.

Finally, another readily available example may be found in a sphere closely related to terrorism: conflict management. In this field, nongovernmental organizations and members of the academic community operate alongside governments and intergovernmental organizations. Unlike official diplomacy, which is carried out by representatives of intergovernmental organizations and state governments, non-official diplomacy (also called "second track diplomacy") ${ }^{14}$ enables attention to concentrate on the community level in order to reveal the problems underlying a conflict and to gather the needed information. At the same time, representatives of non-official diplomacy are often unable to understand the general picture clearly, and sometimes lack sufficient professional training. ${ }^{15}$ This requires that mechanisms of official and non-official diplomacy cooperate in what has become known as "multi-track diplomacy" "multilevel diplomacy.",17

Terrorism is directly linked with security issues, the most sensitive area of interest for any state. Nonetheless, it is assumed that multilevel and multilateral cooperation to counter terrorism is possible, including in the sphere of ideological resistance.

Today, network-based terrorism can easily cross the transparent borders of nationstates. States alone will not be able to create effective barriers to the actions of such terrorist groups; the involvement of other actors is critical. Various programs should be developed to counter terrorism in the ideological sphere (depending on the region, on the people targeted by the program, etc.). Obviously, this will require the cooperation of academic communities in numerous countries as well as representatives of various religious faiths. On a practical level, programs may be implemented by NGOs and representatives of municipal authorities. These same structures may be helpful in terms of collecting feedback, particularly in reporting on the weaknesses of the programs and matters that require special attention. Business structures may provide targeted funding to develop and implement these programs.

14 See V. Volkan, J. Montville, and D. Julius, eds., The Psychodynamics of International Relationships. Vol. II: Unofficial Diplomacy at Work (Lanham, MD: Lexington Books, 1991).

15 See A.S. Natsios, “An NGO Perspective," in Peacemaking in International Conflicts: Methods and Techniques, I. W. Zartman and J.L. Rasmussen, eds. (Washington D.C.: United States Institute of Peace, 1997); P. Aall, "Nongovernmental Organizations and Peacemaking," in Managing Global Chaos: Sources of and Responses to International Conflict, Ch. A. Crocker and F.O. Hampson with P. Aall, eds. (Washington, D.C.: United States Institute of Peace Press, 1996).

16 L. Diamond and J. McDonald, Multi-Track Diplomacy: A System Approach to Peace, 2nd ed. (Washington, D.C.: Institute for Multi-Track Diplomacy, 1993).

17 J.L. Rassmussen, "Peacemaking in the Twenty-First Century: New Rules, New Roles, New Actors,” in Peacemaking in International Conflicts: Methods and Techniques, I. W. Zartman and J. L. Rasmussen, eds. (Washington, D.C.: United States Institute of Peace, 1997). 


\section{Conclusion}

The crisis of Westphalian political order and the lack of a dialogue about a replacement system leads to active operation of extremist and terrorist groups. A struggle against terrorism can be efficient and successful only if attempts are made to frame another political system based on multinational, multilevel dialogue. Such a dialogue will bring no quick solutions, however. Dialogue always requires much patience and time and, according to Mikhail Bakhtin, it creates not just new relations between parties, but also leads to the development of new parties. ${ }^{18}$ At the same time, efforts to maintain the current political system as monolithic and absolute, without any alterations to account for fundamental changes in the global system, will lead only to disappointment, frustration, and further extremist and terrorist action.

So, to develop new, alternative approaches to counter terrorism, the first step should be to establish a long-term dialogue-a network of negotiations, with a wide range of actors - to elaborate principles of the new political system. The second step is to broaden international cooperation in the anti-terrorism struggle. Not only states and intergovernmental organizations should be involved in counter terrorism, but also NGOs, business structures, and academic societies, which have valuable perspectives to offer and important roles to play.

In other words, contemporary efforts to counter terrorism require a comprehensive program that includes a wide variety of actors on a global scale. While this program could be coordinated in a manner similar to the global effort to decode the human genome, it will be a more complex effort in terms of the number of participants it involves, the variety of these participants, and numerous other parameters. Already elements of such multilevel and multilateral cooperation exist. However, this cooperation will become more effective if this activity becomes comprehensive in nature, and if participants begin an honest discussion of global problems and how they could be resolved.

18 Mikhail Bakhtin, Problemy poetiki Dostoevskogo (Moscow: Khudozhestvennaya literatura, 1972); available in English as Problems of Dostoevsky's Poetics (Minneapolis: University of Minnesota Press, 1984). 


\section{Bibliography}

Baran, Zeyno. "Fighting the War of Ideas." Foreign Affairs 84, no. 6 (2005).

Diamond, L., and J. McDonald. Multi-Track Diplomacy: A System Approach to Peace. Washington, D.C.: Institute for Multi-Track Diplomacy, 1993.

Friedman, Thomas L.. The Lexus and the Olive Tree: Understanding Globalization. New York: Farrar, Straus and Giroux, 1999.

Friedman, Thomas. The World Is Flat: A Brief History of the Twenty-first Century. New York: Farrar, Straus and Giroux, 2005.

Fukuyama, Francis. "The End of the History?" The National Interest (1989): 3-18.

Guehenno, Jean-Marie. "Globalization and the International System." Journal of Democracy (1999).

Hoffman, Bruce. Inside Terrorism . London: Victor Gollancz, 1998.

Nye, Joseph S.. The Paradox of American Power: Why the World's Only Superpower Can't Go It Alone. New York: Oxford University Press, 2002.

Orlov, V., and A. Khlopkov. "Na povestke dnya-superterrorism." Nezavisimoye Voennoe Obozrenie (2001).

Rassmussen, J. L.. "Peacemaking in the Twenty-First Century: New Rules, New Roles, New Actors." In Peacemaking in International Conflicts: Methods and Techniques. Washington, D.C.: United States Institute of Peace, 1997. 